Original article

\title{
Acute hepatitis A virus infection in patients hospitalised at the Department of Infectious Diseases, Medical University of Lublin (Eastern Poland) in the years 2009-2015
}

\author{
Joanna M. Krzowska-Firych', Georgia Lucas², Christiana Lucas², Marcin Łukowski², Dawid Maciak², Krzysztof Tomasiewicz' \\ 'Department of Infectious Diseases, Medical University of Lublin, Poland \\ ${ }^{2}$ Clinical Research Association for Infectious Disease at the Department of Infectious Diseases, Medical University of Lublin, Poland
}

\begin{abstract}
The aim of our study was to analyse all medical records from the years 2009-2015 for adult patients with acute hepatitis A virus (HAV) infection who were hospitalised at the Department of Infectious Diseases, Medical University of Lublin (Eastern Poland). During this 7-year study, there were only 5 hospitalised patients with confirmed HAV infection. In the study group 4 out of 5 patients had travelled to HAV-endemic areas (Egypt, Ukraine), and 3 of the hepatitis A cases were imported from Egypt. Our data indicate that during the past 7-year period most HAV patients hospitalised at the Department of Infectious Diseases in Lublin were due to travel.
\end{abstract}

Key words: hepatitis A virus (HAV) infection, epidemiology, Eastern Poland, travellers.

Address for correspondence

Joanna M. Krzowska-Firych, PhD, Department of Infectious Diseases, Medical University of Lublin, 16 Staszica St., 20-089 Lublin, Poland, e-mail: firychjdr@poczta.onet.pl

\section{Introduction}

Hepatitis A virus (HAV) infection is one of the most common causes of acute hepatitis worldwide [1]. Approximately 1.5 million clinical cases occur worldwide annually, but the rate of infection is probably 10 times higher [2]. Hepatitis A virus is a positive-sense, single-stranded RNA virus classified within the genus Hepatovirus of the family Picornaviridae [3]. The chief mode of transmission for HAV is through the faecaloral route, including person-to-person spread, and contaminated water or food products, but it has also been associated with outbreaks in injecting drug users and men who have sex with men $[4,5]$. The virus is very resistant in the environment as well as to several preservation methods (acidification or freezing) [6]. The clinical presentation of HAV generally varies with age. In children under the age of five, approximately $80-95 \%$ of cases are asymptomatic. In contrast, only $10-$ $25 \%$ of adults present asymptomatically [7]. The geogra- phical distribution of HAV is closely related to socioeconomic factors. In low socioeconomic areas with overcrowded households, and low levels of sanitation (Africa, parts of Asia and Latin America) there is a high prevalence of HAV infection. In developing countries the prevalence can be described as intermediate, where sanitary conditions are also more variable. Developed countries (Western Europe, Australia and America) have a lower prevalence of HAV, while Northern Europe and Japan are considered as areas with a very low occurrence [4]. In low endemic countries, hepatitis A mainly affects groups at high risk of infection such as homosexual men, intravenous drug users, and travellers to high endemic areas [8, 9]. Sanitation and standard of living are both factors associated with HAV; an improvement in these has been shown to contribute to a reduction of HAV cases [10]. In addition, since the introduction of the formaldehyde-inactivated vaccine in the 1990s, drastic changes have been seen in the epidemiology of HAV $[11,12]$. In Poland, there has been 
Table 1. Epidemiological information about hepatitis A patients hospitalised in the years 2009-2015 at the Department of infectious Diseases, Medical University of Lublin, Poland

\begin{tabular}{cccccc}
\hline Year & Gender & Age (years) & Travel history (country) & Duration of hospitalisation (days) & Place of residency \\
\hline 2009 & M & 26 & Ukraine & 16 & City \\
\hline 2010 & M & 20 & - & 17 & Village \\
\hline 2011 & - & - & - & - & - \\
\hline 2012 & F & 24 & Egypt & Cgypt & City \\
\cline { 2 - 6 } & F & 26 & Egypt & 9 & City \\
\hline 2013 & - & 28 & - & - & - \\
\hline 2014 & - & - & - & - & - \\
\hline 2015 & - & - & - & - & - \\
\hline M- male, F- female & & - & &
\end{tabular}

a shifting epidemiology of HAV. Before 1997, the incidence of hepatitis A in Poland was high, ranging from 155 per 100000 population to 196 per 100000 population. Due to progressive improvements in working and living conditions in the country, mainly the gradual introduction of sanitation and hygiene measures, the incidence of hepatitis A has decreased considerably in the years since 1997 [13].

The aim of our study was to assess the total number of acute hepatitis A cases in adult patients hospitalised at the Department of Infectious Diseases, Medical University of Lublin in the years 2009 to 2015 . We also analyzed epidemiological data and the clinical course of patients with acute HAV infection.

\section{Material and methods}

We retrospectively analysed medical records of all adult patients with acute HAV infection who were hospitalised at the Department of Infectious Diseases, Medical University of Lublin. The epidemiological and clinical data were analysed.

\section{Results}

In the studied period, 2009-2015, acute HAV infection was confirmed in 5 patients hospitalised at the Department of Infectious Diseases, Medical University of Lublin (Eastern Poland). All of these patients were included in our study. In all patients, anti-HAV IgM antibodies were detected on admission. In all of them serological markers of hepatitis $B(\mathrm{HBV})$ and hepatitis $\mathrm{C}$ $(\mathrm{HCV})$ infection were negative. None of them were vaccinated against HAV. In the study group there were
3 men and 2 women, all Polish citizens; 4 out of 5 were inhabitants of cities, and 1 was resident in a village. The median age was 24.8 years (range: 20-28) (Table 1 ).

In 2009, the 26-year-old male patient was admitted to our hospital due to jaundice, flu-like symptoms, and malaise. The onset was abrupt and the first symptoms occurred 7 days after he returned from a business trip to Ukraine. Physical examination revealed scleral icterus, jaundice, and hepatomegaly. Admission laboratory evaluation demonstrated a total bilirubin increase $(7.9 \mathrm{mg} \%)$, elevated alanine aminotransferase (ALT), aspartate aminotransferase (AST), and gamma-glutamyltransferase (GGTP) level. The ALT value was $1643 \mathrm{U} / \mathrm{l}$, AST was $703 \mathrm{U} / \mathrm{l}$, and GGTP increased to $570 \mathrm{U} / \mathrm{l}$. On day 5 of admission the total bilirubin increased to $10.8 \mathrm{mg} \%$, and liver enzymes increased to $2148 \mathrm{U} / \mathrm{l}$ (ALT) and to $905 \mathrm{U} / \mathrm{l}$ (AST). The prothrombin index was normal. We did not observe any symptoms of liver failure. The time of hospitalisation was 16 days. On discharge his total bilirubin was $1.39 \mathrm{mg} \%$, and the level of ALT was $487 \mathrm{U} / \mathrm{l}$. The patient fully recovered 3 weeks after discharge from the hospital. The next year (2010), the 20-yearsold male patient was admitted to the hospital due to jaundice, fatigue and abdominal pain. His physical examination was normal except scleral icterus, and jaundice. He did not report any recent travel, or any contact with travellers or people with HAV infection. The total bilirubin level on admission was $6.23 \mathrm{mg} \%$, the ALT level was $1946 \mathrm{U} / \mathrm{l}$, the AST was $764 \mathrm{U} / \mathrm{l}$, and GGTP was 393 U/l. During 17-day long hospitalisation no complications were observed. On discharge the total bilirubin level was $1.93 \mathrm{mg} \%$, ALT was $203 \mathrm{U} / \mathrm{l}$, AST was $47 \mathrm{U} / \mathrm{l}$, and GGTP was $142 \mathrm{U} / \mathrm{l}$. The patient had fully 
recovered one week after discharge from the hospital. In 2011, there were no patients with hepatitis A infection. In 2012, there were 3 patients diagnosed with HAV infection. All of them reported recent 7-day long tourist travel to Egypt. One of these patients was a 20-year-old woman. She was admitted to the hospital due to nausea, vomiting, fever and jaundice. The first symptoms occurred 10 days after she returned from Egypt. Her physical examination was normal except scleral icterus, jaundice and enlarged liver. On admission she presented elevated total bilirubin concentration (9.04 mg\%), elevated ALT (2462 U/l) and AST (2216 U/l), and elevated GGTP (197 U/l). The time of hospitalization was 20 days, and no complications were observed. On discharge her total bilirubin was $2.25 \mathrm{mg} \%$, ALT level was $185 \mathrm{U} / \mathrm{l}$, AST was $64.3 \mathrm{U} / \mathrm{l}$, and GGTP was normal. Another patient was a 26-year-old woman. Before hospitalisation she suffered from nausea, loss of appetite, vomiting, malaise, and abdominal pain. The first symptoms occurred 3 weeks after she returned from Egypt. The physical examination revealed jaundice and enlarged liver. Admission laboratory evaluation demonstrated an elevated total bilirubin level (14 mg\%), elevated ALT (3787 U/l), elevated AST (2766 $\mathrm{U} / \mathrm{l})$, and GGTP (348 U/l). She was hospitalised for 20 days, and no complications were observed. On discharge her bilirubin was $4.38 \mathrm{mg} \%$, ALT was $148 \mathrm{U} / \mathrm{l}$, AST was $112 \mathrm{U} / \mathrm{l}$, and GGTP was $235 \mathrm{U} / \mathrm{l}$. She had fully recovered 2 weeks after discharge from the hospital. In the same year a 28-year-old male patient was hospitalised due to acute HAV infection. The history revealed that he developed symptoms from the gastrointestinal tract (nausea, vomiting) and intermittent fever 3 weeks after he returned from Egypt. The physical examination an admission was normal except jaundice and enlarged liver. The total bilirubin level was $4.91 \mathrm{mg} \%$, ALT was $2260 \mathrm{U} / \mathrm{l}$, AST was $1289 \mathrm{U} / \mathrm{l}$, and GGTP was $614 \mathrm{U} / \mathrm{l}$. The clinical course was without any complications. On discharge the total bilirubin level was $2.4 \mathrm{mg} \%$, ALT was $487 \mathrm{U} / \mathrm{l}$, AST was $88.9 \mathrm{U} / \mathrm{l}$, and GGTP was $315 \mathrm{U} / \mathrm{l}$. The patient was hospitalised for 9 days and had fully recovered 10 days after discharge. In the period 20132015 , there were no cases of hospitalised HAV infection in this department.

The epidemiological investigation revealed that 4 out of the 5 patients with HAV infection had travelled to hepatitis A endemic areas. In one patient hospitalised in 2010, there was no history regarding travels or any other risk factors. He was a resident of a village in the Lublin province. In all patients an abrupt onset of infection was observed, and they all developed jaundice with mean concentration of bilirubin at $8.9 \mathrm{mg} \%$. In all patients, an increase of serum aminotransfer- ases levels was detected. The mean serum ALT level was $2520 \mathrm{U} / \mathrm{l}$, mean AST was $1420 \mathrm{U} / \mathrm{l}$, and the mean GGTP was $364.6 \mathrm{U} / \mathrm{l}$. All our patients recovered with no clinical sequelae, and the medium time of hospitalization was 16.4 days.

\section{Discussion}

Data from our study indicate that during this 7-year period, HAV infection was diagnosed in only 5 patients hospitalised at the Department of Infectious Disease, Medical University of Lublin. The available epidemiological data indicate that Poland currently has the features typical for areas of very low endemicity with respect to HAV infection [14].

It should be pointed out that data from our study only partially reflect epidemiology of HAV infection in Lublin province, because there are also other infectious disease departments in this part of Poland. General trends in Poland show that there has been a decreasing number of cases. In our department only 5 patients were hospitalised during 2009-2015 with HAV infection, but in 2008 we recorded 18 cases. In 2009, there was a peak incidence of HAV with 562 confirmed cases [15]. In 2010, 155 cases of hepatitis A were reported in Poland and the incidence rate was 0.41 per 100000 population. In 2010, 5 foodborne outbreaks involving 10 cases were noted. The incidence of HAV infection in Poland in 2010 compared to the previous 2 years was lower [16]. The notification rate in the European Union for HAV has been steadily decreasing over the last 15 years, from 14.0 in 1997 to 2.6 per 100000 population in 2010. This overall decline in the notification rate most likely reflects improved living conditions, as HAV seroprevalence rates are strongly correlated with socioeconomic status and access to clean water and sanitation [17]. In 2011, there were only 65 registered cases of HAV in Poland [18]. In contrast to 2011, there was a slight increase in the occurrences of HAV in 2012, with 71 recorded cases. These cases in 2012 continued to show seasonality, being highest when people returned from holidays in highly endemic countries [19]. Our department also observed the highest number of hospitalised patients in 2012, and all of them developed hepatitis after returning from endemic areas. In 2013, only 48 cases of HAV infection were diagnosed in Poland, and imported cases accounted for $45.8 \%$ of the total number of hepatitis A cases. There were three outbreaks involving 13 cases [20]. In 2014, 76 cases of hepatitis A were officially detected in Poland, which was higher than in the previous year. In 2015, 49 cases were noted for this country, but also like in the 2 previous years without a single case in our 
department [21]. During the studied 7-year period patients with HAV infection comprised the smallest group of all our patients hospitalised due to acute viral hepatitis. From 2009-2015 in our department 13 patients were hospitalised with confirmed acute HBV infection, and 10 with acute HCV infection (Table 2).

The decline in the incidence of HAV infection was also noted in Western Europe, Greece, USA, Australia, China, Japan and several countries in Southeast Asia [22]. The prevalence of hepatitis A does not exceed 4 per 100000 population in the European Union [23]. All our patients were young adults with the medium age of 24.8 years. The epidemiological study performed by Bura et al. showed that susceptibility to HAV infection among young adults is common [24]. The data presented by Polz-Dacewicz et al. showed that higher prevalence of antibody to HAV was found in subjects older than 50 years (75.8\%) [25]. In all our patients, the clinical course of hepatitis A infection presented symptomatically with abrupt onset and jaundice. The main factor that influences the clinical course of primary HAV infection is the age of an infected patient. The data presented by Stapleton et al. indicate that HAV infection was symptomatic in only $4-16 \%$ of children, compared with $75-95 \%$ of adults. In another study of young adults with HAV infection, $76-97 \%$ presented with symptoms, and 40-70\% developed jaundice [26].

In our study we observed no complications, and all patients fully recovered with no clinical sequelae. This infection is generally self-limited, but it can range from asymptomatic to fulminant hepatitis. Rapp et al. described a case of cholestatic HAV infection complicated by renal failure and haemolytic anaemia [27]. The case-fatality ratio in patients with acute hepatitis A infection is low $(0.1-0.3 \%)$ but might be higher $(1.8 \%)$ in adults over 50 years of age or persons with chronic liver diseases [2].

Hepatitis A virus infections in developed countries still occur and are mainly associated with travel. The epidemiological analysis of our patients revealed that 4 of them had travelled to HAV-endemic areas. One person had travelled to Ukraine for business, and 3 patients had travelled to Egypt for a 7-day tourist trip. According to current epidemiological data, hepatitis $\mathrm{A}$ is the second most common infectious disease in travellers [28].

Non-immune travellers are at risk of contracting the disease during travels to countries of high or intermediate endemicity. Currently, with improvements in sanitary conditions, the risk of infection for nonimmune travellers who visit high or medium-endemic areas has been reduced. In the past the risk of HAV infection in unvaccinated travellers was considered to be 3 per 1,000 individuals per month of travel. The epide-
Table 2. Total number of acute viral hepatitis A, B, and C patients hospitalised in the Department of Infectious Diseases, Medical University of Lublin, Poland in the years 2009-2015

\begin{tabular}{cccc}
\hline & $\begin{array}{c}\text { Total number } \\
\text { of acute HAV } \\
\text { infections }\end{array}$ & $\begin{array}{c}\text { Total number } \\
\text { of acute HBV } \\
\text { infections }\end{array}$ & $\begin{array}{c}\text { Total number } \\
\text { of acute HCV } \\
\text { infections }\end{array}$ \\
\hline 2009 & 1 & 1 & - \\
\hline 2010 & 1 & 3 & 1 \\
\hline 2011 & - & 4 & 4 \\
\hline 2012 & 3 & 4 & 1 \\
\hline 2013 & - & 1 & 2 \\
\hline 2014 & - & - & 2 \\
\hline 2015 & - & - & - \\
\hline Total number & 5 & 13 & 10 \\
\hline
\end{tabular}

miological data demonstrated that the areas associated with the highest incidence of disease were East Africa, the Middle East, and the Indian subcontinent [29]. Hepatitis A virus infection in 26 tourists with a history of travel to Egypt has been reported in France, and the most likely source of infection was a Nile river cruise that was a common factor in the majority of these cases. In 2004, 351 tourists who travelled to Egypt from 9 European countries were infected with HAV, which was likely due to consumption of contaminated orange juice [30,31]. In our material only 1 patient did not travel to HAV-endemic areas and no risk factors were found. Some authors have suggested that young adults have the potential to be exposed more than older people to other well-known risk factors of HAV infection such as use of intravenous drugs, occupational exposure, homosexual practices and multiple and occasional sexual contacts [7].

\section{Conclusions}

1. Among patients with confirmed HAV infection hospitalised at the Department of Infectious Diseases, Medical University of Lublin, Poland, 4 out of 5 persons had travelled to HAV-endemic areas (Egypt and Ukraine).

2. Most HAV infections were observed in 2012, and all cases were imported from Egypt.

3. None of our patients were vaccinated against HAV, which indicates that young adults (under 30 years of age) are susceptible to HAV infection.

\section{Disclosure}

Authors report no conflict of interest. 


\section{References}

1. Centers for Disease Control Prevention. Prevention of hepatitis A through active or passive immunization: Recommendation of the Advisory Committee on Immunization Practices (ACIP). MMWR Recomm Rep 1999; 48 (RR-12): 1-37.

2. Koff RS. Hepatitis A. Lancet 1998; 351: 1643-1649.

3. Lemon SM. HAV: current concepts of the molecular virology, immunobiology and approaches to vaccine development. Rev Med Virol 1992; 2: 73-87.

4. WHO. The Global Prevalence of Hepatitis A Virus Infection and Susceptibility: A Systematic Review; available at: whqlibdoc.who.int/hq/2010/WHO_IVB_10.01_eng.pdf.

5. Widell A, Hansson BG, Moestrup T, et al. Increased occurrence of hepatitis A with cyclic outbreaks among drug addicts in a Swedish community. Infection 1983; 11: 198-200.

6. Butot S, Putallaz T, Sánchez G. Effects of sanitation, freezing and frozen storage on enteric viruses in berries and herbs. Int J Food Microbiol 2008; 126: 30-35.

7. Lednar WM, Lemon SM, Kirkpatrick JW, et al. Frequency of illness associated with epidemic hepatitis A virus infections in adults. Am J Epidemiol 1985; 122: 226-233.

8. Stene-Johansen K, Jenum PA, Hoel T, et al. An outbreak of hepatitis A among homosexuals linked to a family outbreak. Epidemiol Infect 2002; 129: 113-117.

9. Tjon GM, Gotz H, Koek AG, et al. An outbreak of hepatitis A among homeless drug users in Rotterdam, The Netherlands. J Med Virol 2005; 77: 360-366.

10. Jenson $\mathrm{HB}$. The changing picture of hepatitis $\mathrm{A}$ in the United States. Curr Opin Pediatr 2004; 16: 89-93.

11. WHO position paper on hepatitis A vaccines - June 2012. Wkly Epidemiol Rec 2012; 87: 261-276.

12. WHO: The immunological basis for immunization series: module 18- hepatitis A. World Health Organization, Geneva 2010; http://whqlibdoc.who.int/publications/2011/9789241501422_ eng.pdf.

13. Janaszek-Seydlita W, Bucholc B, Wiatrzyk A. Prevalence of anti-HAV antibodies in Warsaw population. Przegl Epidemiol 2007; 61: 675-682.

14. Magdzik W, Czartkowski MP. Zmiany w endemiczności wirusowego zapalenia wątroby typu A (WZW A) w Polsce. Przegl Epidemiol 2004; 58: 3-8.

15. Baumann-Popczyk A. Hepatitis A in Poland in 2009. Przegl Epidemiol 2011; 65: 255-258.

16. Baumann-Popczyk A. Hepatitis A in Poland in 2010. Przegl Epidemiol 2012; 66: 273-276.

17. European Centre for Disease Prevention and Control. Annual epidemiological Report 2012. Reporting on 2010 surveillance data and 2011 epidemic intelligence data. ECDC, Stockholm 2013.

18. Baumann-Popczyk A. Hepatitis A in Poland in 2011. Przegl Epidemiol 2013; 67: 235-238.

19. Baumann-Popczyk A. Hepatitis A in Poland in 2012. Przegl Epidemiol 2014; 68: 253-256.

20. Baumann-Popczyk A. Hepatitis A in Poland in 2013. Przegl Epidemiol 2015; 69: 247-250.

21. Zakład Epidemiologii NIZP-PZH. Zachorowania na wybrane choroby zakaźne w Polsce od 1 stycznia do 31 grudnia 2015. Meldunek Roczny.

22. Gust ID. Epidemiology patterns in hepatitis A in different parts of the world. Vaccine 1992; 10 (S1): 56-58.

23. Payne L, Coulombier D. Hepatitis A in the European Union: responding to challenges related to new epidemiological patterns. Euro Surveill 2009; 14: pii: 19101.
24. Bura M, Bura A, Adamek A, et al. Seroprevalence of hepatitis A virus antibodies (anti-HAV) in adult inhibitants of Wielkopolska region, Poland - the role of simple demographic factors. Ann Agric Environ Med 2012; 19: 738-741.

25. Polz-Dacewicz MA, Policzkiewicz P, Badach Z. Changing epidemiology of hepatitis A virus infection - a comparative study in Central Eastern Poland (1990-1999). Med Sci Monit 2000; 6: 989-993.

26. Stapleton TJ, Lemon SM. Infectious diseases. In: Hepatitis A and hepatitis E. Hoeprich PD, Jordan MC, Ronald AR (eds.). $5^{\text {th }}$ ed. Saunders, Philadelphia 1994; 790-800.

27. Lapp RT, Rochling F. Acute cholestatic hepatitis A virus infection presenting with hemolytic anemia and renal failure: a case report. Case Reports Hepatol 2013; 2013: 438375.

28. Yung A, Ruff T, Torresi J, et al. Manual of travel medicine: a pretravel guide for health care practitioners. $2^{\text {nd }} \mathrm{ed}$. IP Communications, Melbourne 2004.

29. Askling $\mathrm{HH}$, Rombo L, Andersson $\mathrm{Y}$, et al. Hepatitis A risk in travelers. J Travel Med 2009; 16: 233-238.

30. Couturier E, Roque-Afonso AM, Letort MJ, et al. Cluster of cases of hepatitis A with a travel history to Egypt, September-November 2008, France. Euro Surveill 2009; 14 pii: 19094.

31. Frank C, Walter J, Muehlen M, et al. Major outbreak of hepatitis A associated with orange juice among tourists, Egypt, 2004. Emerg Infect Dis 2007; 13: 156-158. 